\title{
O "SISTEMA" DA MORAL? UMA INVESTIGAÇÃO SOBRE A SISTEMATICIDADE INTERNA DA METAFÍSICA DOS COSTUMES DE KANT
}

\author{
Diego Kosbiau Trevisan* \\ diegokosbiau@hotmail.com
}

RESUMO $O$ artigo tem como objetivo pôr em questão duas objeções comumente lançadas contra a "Metafisica dos Costumes", a saber, a sua falta de "clareza sistemática" quando comparada com outras obras críticas centrais de Kant, e também a admissão aparentemente equivocada da legalidade como conceito legítimo de um sistema metafísico prático. Argumentar-se-á que a identificação do ato do livre arbitrio como conceito supremo do sistema permite responder às críticas lançadas ao, por um lado, apresentar um princípio de ordenação sistemática empregado de forma análoga em outras obras reconhecidamente sistemáticas, e, por outro, justificar a posição central ocupada no sistema pelo ato correto ou conforme ao dever, ensejando a possibilidade de que tanto o Direito quanto a legalidade ética sejam concebidos como autênticos elementos de uma "Metafisica dos Costumes".

Palavras-chave Kant, Direito, Ética, Sistema, Metafísica.

ABSTRACT This paper casts doubt on two objections commonly raised against the "Metaphysics of Morals", namely, its lack of "systematic consistency" when compared with other central works of Kant's critical 
philosophy and also the apparently misleading admission of legality as a legitimate concept of his practical metaphysical system. It will be argued that the identification of the act of free choice as the supreme concept of the system allows us to face these criticisms firstly by presenting a principle of systematic arrangement which is employed in other admittedly systematic works, and secondly by justifying the central position occupied by the right act, or the action in conformity with duty in Kant's system of morals, which allows for the possibility that both Law and ethical legality be considered as authentic elements of a "Metaphysics of Morals".

Keywords Kant, Law, Ethics, System, Metaphysics.

A "Metafísica dos Costumes", ${ }^{1}$ composta pelos "Primeiros Princípios Metafísicos da Doutrina do Direito" e pelos "Primeiros Princípios Metafísicos da Doutrina da Virtude", é uma obra que possui um curioso estatuto no interior do corpus kantiano - embora tenha sido um dos primeiros e mais caros projetos de Kant por ocasião das formulações iniciais acerca do que viria a ser a sua filosofia crítica, ${ }^{2}$ a tardia "Metafísica dos Costumes", publicada apenas em 1797, despertou críticas de significativos filósofos e comentadores, que colocaram em questão o valor da obra quando tomada em conjunto com as demais realizações filosóficas de Kant e tacharam-na de a maior decepção do projeto crítico.

À parte objeções de duvidoso valor filosófico - como, por exemplo, Schopenhauer (1988, pp. 667-668) e a acusação de uma suposta senilidade de Kant; Hannah Arendt (1992, pp. 7-8) e sua reprovação da pobreza e aridez dos temas tratados; e também Victor Delbos (1969, p. 559) e a denúncia de falta de uma "dedução sistemática rigorosa" em virtude da "senilidade extrema" de

1 As obras de Kant são citadas de acordo com o seguinte modelo (FMC Ak IV 388. p. 103), ou seja, a abreviação (presente nas Referências) do nome da obra seguida do volume e da página da edição da Academia e da página da edição em português correspondente. Nas citações da "Crítica da Razão Pura", a página da edição da Academia é substituída pela mais convencional citação "B", correspondente à segunda edição da obra. Nas citações da "Metafísica dos Costumes", a abreviação do nome em português de cada parte sucede a referência à obra da Academia. Frequentemente modificamos a tradução em português presente nas Referências. Por fim, as traduções de trechos de obras sem edição em português são de nossa autoria.

2 Sobre a genealogia do termo "Metafísica dos Costumes" e suas reviravoltas no decorrer dos períodos pré-crítico e crítico de Kant, ver Alain Renaut (1994, pp. 8-21), Lewis White Beck (1960, pp. 5-18) e Monika Sänger (1982, pp. 13-74, esp. 13-26). 
$\mathrm{Kant}^{3}$-, as críticas à "Metafísica dos Costumes" filosoficamente relevantes giram em torno de basicamente dois pontos: em primeiro lugar, a sua pretensa falta de "clareza" sistemática, seja no interior da "arquitetônica da razão prática", seja quando tomada em comparação, por exemplo, aos "Primeiros Princípios Metafísicos da Ciência da Natureza", obra que é seu correlato metafísico no terreno teórico $;^{4}$ e, em segundo lugar, a introdução de certas construções argumentativas que contradizem - ou ao menos conflitam com - aquilo que fora exposto na "Fundamentação da Metafísica dos Costumes" e na "Crítica da Razão Prática", a saber, o surgimento do Direito como uma disciplina pertencente à parte metafísica da filosofia moral de Kant, e, relacionado a isso, o acolhimento da legalidade $<$ Legalität $>, 5$ em oposição à moralidade $<$ Moralität $>$, como um conceito legítimo do sistema metafísico prático kantiano, passível de ser aplicado mesmo àqueles deveres que exigem a adoção de fins que são ao mesmo tempo deveres, ou seja, aos deveres de virtude, o que num primeiro olhar parece contraditório. ${ }^{6}$

Uma tentativa de reconduzir a "Metafísica dos Costumes" ao posto de grande realização filosófica de Kant - como, de resto, parece ser a voga de tempos para cá ${ }^{7}$ - será ensaiada aqui por meio de uma resposta unificada a essas duas grandes objeções ao estudo da obra. Para tanto, buscaremos, com auxílio de uma passagem da própria "Metafísica dos Costumes", lançar mão do conceito de ato do livre arbítrio como princípio sistemático de divisão da obra em "Doutrina do Direito" e "Doutrina da Virtude". Isso permitirá, num primeiro momento, restituir à "Metafísica dos Costumes" uma "dignidade sistemática" pretensamente ausente nela e constitutiva das demais grandes

3 Sobre as críticas de Schopenhauer e Hannah Arendt, bem como as tentativas de resposta à "tese da senilidade", compartilhada de uma forma geral pelo movimento do neokantismo do final do séc. XIX e início do XX, ver Katrin Flikschuh (2000, pp 8-9; 1999, p. 250n1).

4 Sobre essa acusação em geral, além de Victor Delbos (1969), ver p. ex. L. W. Beck (1960, pp. 10; 14; 534) e H. J Paton (1971, pp. 31-3). Sobre o caso específico da Doutrina do Direito, ver a vasta bibliografia fornecida por Monika Sänger na introdução de seu livro (1982, pp. 3-12) a respeito do pretenso "fracasso" $<$ Scheitern> de uma metafísica sistemática do Direito em Kant.

5 Cumpre não confundir Legalität com Gesetzmäßigkeit - embora se tenha convencionado traduzir ambos os termos por legalidade, Kant parece reservar o segundo para a esfera jurídica (cf. DD Ak VI 214. p. 18) e o primeiro tanto para a esfera jurídica quanto para a esfera ética (cf. DV Ak VI 398. p. 33). Contudo, não há tanto rigor nessa distinção, como mostra DD Ak VI 225. p. 31, em que Gesetzmäßigkeit designa a "coincidência de uma ação com a lei do dever", num significado aparentemente similar ao de Legalität nas passagens mencionadas acima.

6 Sobre o caso do Direito, ver Allen Wood (1999; 2002) e Marcus Willaschek (2002). Sobre a aparente contradição em termos de uma legalidade ética, ver p. ex. Marcia Baron (1995).

7 O primeiro estudo verdadeiramente sistemático da "Metafísica dos Costumes" é de Mary J. Gregor (1963). Depois desse trabalho pioneiro, vieram outras obras que buscaram analisar a "Metafísica dos Costumes" sob uma chave genuinamente sistemática, e não meramente tópica. Cf. p. ex. Alain Renaut (2000). Hans Friedrich Fulda (2001) e Paul Guyer (2005). E sobretudo Monika Sänger (1982) relativamente à Doutrina do Direito. 
obras kantianas; e, num segundo momento, reconhecer, no interior desse novo registro sistemático, o lugar legítimo da ação conforme ao dever, isto é, da legalidade, no interior da filosofia moral kantiana, inversamente ao que é aparentemente sustentado na "Fundamentação" e na "Crítica da Razão Prática". Argumentaremos que a elevação do ato conforme ao dever, ou ainda, do ato "correto" <recht $>$, a conceito supremo de uma "Metafísica dos Costumes", tornará compreensível, de um ponto de vista sistemático, a figuração do Direito numa filosofia moral kantiana, além de enriquecê-la ao permitir a distinção entre motivação subjetiva e conformação objetiva ao dever nos deveres de virtude.

\section{Ato do livre arbítrio como conceito supremo}

A ânsia sistemática é uma pecha com a qual se costuma tachar a filosofia kantiana, não raro identificando-a como um vezo do qual Kant deveria ter aberto mão. $O$ fato é que uma tentativa consequente de reconstrução do edifício filosófico de Kant não pode furtar-se a levar a sério as exigências sistemáticas levantadas pelo próprio filósofo e tidas por ele como centrais em seu esforço crítico. O que parece ocorrer é que muitas vezes a recusa em conferir importância às pretensões de sistematicidade por parte do comentador é reflexo das dificuldades encontradas na compreensão do que Kant entendia por elas e do modo pelo qual deveriam ser cristalizadas no edifício crítico. Apresentarei na sequência um caminho entre outros possíveis para o comentador cioso de uma interpretação verdadeiramente sistemática da filosofia kantiana, em especial da "Metafísica dos Costumes".

Vejamos o que Kant escreve na "Crítica da Razão Pura" ao final do apêndice relativo à "Anfibologia dos Conceitos de Reflexão", a poucas linhas do término da "Analítica Transcendental":

Antes de deixarmos a analítica transcendental, temos ainda que acrescentar algo que, embora não sendo em si de particular relevo, poderia parecer necessário para completude do sistema: O mais alto conceito, com o qual se costuma começar uma filosofia transcendental consiste unicamente na divisão em possível e impossível. Todavia, visto que toda a divisão pressupõe um conceito dividido, tem que ser indicado um conceito ainda mais alto, e este é o conceito de um objeto em geral (tomado problematicamente e sem decidir se é alguma coisa ou nada). Já que as categorias são os únicos conceitos que se referem a objetos em geral, procede a distinção, se um objeto é alguma coisa ou nada, segundo a ordem e indicação das categorias (CRP B 346. p. 227, grifo meu).

Nesse trecho, Kant afirma que a identificação de um conceito supremo no sistema transcendental enseja uma preciosa indicação sistemática que, 
embora não tenha sido explicitamente levada a cabo na "Analítica", pode parecer atraente àquele que busca reconstruir de forma completa o sistema da filosofia transcendental. Se, como repetidas vezes foi ressaltado ao longo da "Analítica", as categorias apresentam as condições de possibilidade de um objeto da experiência, parece evidente que, de uma perspectiva lógica, o sistema da filosofia transcendental deva possuir como conceito supremo aquele de um objeto em geral, restando às categorias determinar de que forma esse conceito poderia ser legitimamente constituído no interior dos limites da experiência sensível - trata-se do conhecido projeto de substituição da "soberba" ontologia por uma "modesta" analítica do entendimento puro (cf. CRP B 303. p. 206). De forma análoga, nos "Primeiros Princípios Metafísicos da Ciência da Natureza", que trata não de objetos em geral ou de objetos conforme estes são dados a uma intuição sensível em geral, mas de objetos conforme estes são dados ao sentido externo, "põe-se como fundamento uma análise completa do conceito de uma matéria em geral" (PMCN Ak IV 472. p. 17, grifo meu), o qual, a exemplo do que ocorre com o conceito de objeto em geral na filosofia transcendental, assume o posto de conceito supremo do sistema metafísico da natureza. ${ }^{8}$

É duvidoso, decerto, que Kant tenha de fato desejado que seu sistema fosse concebido de acordo com esse modelo tipicamente racionalista - ou seja, que de um conceito ou de um princípio supremo pressuposto toda a dedução das partes do sistema fosse feita sem recurso a outras fontes que não a razão e sua consistência interna. Pelo contrário, como os próprios "Primeiros Princípios Metafísicos da Ciência da Natureza" claramente demonstram, são necessários procedimentos críticos de aplicação das proposições teóricas fundamentais a certos elementos empíricos mínimos presentes no âmbito da experiência do qual se pretende erigir um sistema - para não mencionar, decerto, todo o esforço crítico de demonstração da realidade objetiva dos conceitos ou princípios assumidos como supremos na dedução de um tal sistema. ${ }^{9}$ Contudo, como é indicado no trecho da "Anfibologia", a identificação de um conceito supremo pode ser de grande serventia àquele que busca a completude do sistema ao apresentar um princípio, um fio condutor lógico-sistemático a partir do qual, e com o auxílio dos expedientes críticos, o sistema deva ser elaborado. Trata-se não de um capricho do construtor do sistema, mas

8 Considerando-se, decerto, a impossibilidade de haver uma metafísica da substância pensante, do objeto do sentido interno (Cf. PMCN Ak IV 471).

9 Dentre as obras que se esforçam em reconstituir a sistemática interna dos "Primeiros Princípios Metafísicos da Ciência da Natureza”, destacam-se as obras de M. Friedman (2013), P. Plaass (1965) e J. Vuillemin (1987). 
sim de uma valiosa indicação acerca do caminho a ser, implicitamente ou não, trilhado. Sendo assim, uma "Metafísica dos Costumes", se de fato Kant quis conferir-lhe sistematicidade, deve, a exemplo das demais obras, possuir um conceito supremo dividido a servir de guia para sua elaboração. Onde, contudo, procurá-lo? Quem dá a pista é o próprio Kant em nota a uma seção da Introdução à "Metafísica dos Costumes":

A dedução da divisão de um sistema, isto é, a prova da sua integralidade, como também da sua continuidade - a saber, que a passagem dos conceitos divididos para os membros da divisão ocorra na série completa das subdivisões sem nenhum salto (divisio per saltum) -, é uma das condições mais difíceis que o construtor de um sistema deve satisfazer. Difícil é também determinar qual é o conceito supremo dividido na partilha do correto e do incorreto <recht oder unrecht $>$ (aut fas aut nefas). É o ato do livre arbitrio em geral. Assim acontece aos mestres de ontologia, que começam por algo ou nada como o primeiro, sem advertirem que são já membros de uma divisão, cujo conceito dividido falta, e que só pode ser o conceito de um objeto em geral (DD Ak 218n. p. 23n, tradução modificada e grifos meus).

Como se vê, Kant põe em paralelo os procedimentos realizados na ontologia (ou ainda, em nosso contexto, filosofia transcendental), por um lado, e na "Metafísica dos Costumes", por outro: ambas as disciplinas, se se deseja garantir-lhes completude sistemática, devem partir de um conceito supremo dividido - a ontologia, do objeto em geral, e a "Metafísica dos Costumes", do ato do livre arbítrio em geral. Através desse paralelo, Kant torna explícita uma pretensão de sistematicidade inerente à "Metafísica dos Costumes" que, é bem verdade, não encontrou uma plena expressão na obra que levou esse nome. ${ }^{10}$ Não obstante, a presença de um conceito supremo dividido pode servir como uma indicação sistemática acerca da forma pela qual o sistema metafísico prático deveria ter sido erigido - basta ver como o conceito de objeto em geral oferece de modo indireto, após a divisão subsequente entre objeto do mero entendimento (numeno) e objeto dos sentidos (fenômenos) (Cf. KrV A 235-260/B 294-315), a forma do sistema metafísico teórico, com sua divisão em análise do objeto do sentido externo e do objeto do sentido interno. $\mathrm{Na}$

10 Referimo-nos aqui à ausência de uma clara aplicação das proposições morais ao conceito de ato do livre arbítrio, num procedimento análogo àquele realizado nos "Primeiros Princípios da Ciência da Natureza", onde as categorias do entendimento, com auxílio de expedientes matemáticos, são aplicadas ao conceito de matéria, ensejando as quatro subdivisões que nomeiam os capítulos da obra, a saber, foronomia, dinâmica, mecânica e fenomenologia. Mesmo aqui Kant parece ter tido em mente um procedimento análogo na "Metafísica dos Costumes" - basta ver os "Vorarbeiten zur Rechtslehre", presentes no volume XXIII da Academia, onde Kant esboça uma aplicação das categorias da liberdade ao conceito de ato do livre arbítrio no plano jurídico. Em virtude das dificuldades apresentadas ao tema e às fontes textuais em suporte, não iremos nos deter aqui. Uma tentativa de reconstrução desse esforço de aplicação está em Monika Sänger (1982). 
sequência do artigo seguiremos essa indicação sistemática oferecida por Kant e, analisando o conceito de ato do livre arbítrio, discutiremos o que de fato é partilhado por esse conceito supremo e o modo pelo qual a distinção entre legislação ética e legislação jurídica - base para a divisão da obra em "Doutrina do Direito" e "Doutrina da Virtude" - já está implicitamente contida nele, apontando por fim as implicações temáticas que essa interpretação acarreta no conjunto da filosofia moral kantiana, mais especificamente a elevação da legalidade a elemento primordial do sistema.

\section{Análise do ato do livre arbítrio}

A identificação de um conceito supremo dividido do sistema das ciências práticas é apenas um primeiro passo na análise proposta. Ainda é necessário indicar de que forma esse conceito supremo, o ato do livre arbítrio, serve ao propósito de um esboço da divisão de uma "Metafísica dos Costumes" em "Doutrina do Direito" e "Doutrina da Virtude" e da articulação de temas como o Direito e a legalidade ética. Comecemos com uma análise semântica do conceito de ato conforme este é caracterizado na Introdução à "Metafísica dos Costumes", chegando, por fim, à discussão do significado de recht e unrecht como aquilo que é partilhado no sistema cujo conceito supremo é ato de livre arbítrio em geral. Somente após essa análise será possível avaliar de que forma o argumento aqui esboçado ilumina a questão do Direito e da legalidade ética na "Metafísica dos Costumes". ${ }^{11}$

Comecemos analisando o que Kant entende por ato: "Chama-se ato a uma ação na medida em que está submetida a leis da obrigação, portanto, também na medida em que nela o sujeito se considera à luz da liberdade de seu arbítrio" (DD Ak VI 223. p. 28).

11 A análise feita na sequência adota como pressuposto algo que no projeto filosófico mais amplo de Kant carece de justificação, a saber, que o ato do arbítrio pode ser livre - em outros termos, que o conceito supremo da divisão deve ter sua realidade objetiva demonstrada. Segundo Kant, a proposição "a razão pura pode por si mesma ser prática", ou seja, "pode ser livre" (e, por conseguinte, que "o arbítrio pode ser livre") é uma proposição sintética a priori que necessita de demonstração, para a qual Kant, por sua vez, emprega a polêmica argumentação do círculo de prova na terceira seção da "Fundamentação da Metafísica dos Costumes" e, posteriormente, o não menos discutível recurso ao "factum da razão" na "Crítica da Razão Prática". Antes que a acusação de logicismo ou dedutivismo pré-crítico seja levantada, cumpre advertir que é adotada aqui uma postura semelhante àquela que Kant assume na "Metafísica dos Costumes", a saber, que a liberdade como condição de possibilidade de um sistema dos costumes já teve sua realidade objetiva demonstrada no trabalho crítico propedêutico, a exemplo do que ocorre nos "Primeiros Princípios Metafísicos da Ciência da Natureza", a saber, que a realidade objetiva das categorias como condição de possibilidade da experiência em geral já havia sido demonstrada na "Crítica da Razão Pura" por meio da Dedução Transcendental e do Esquematismo. 
Um ato não pode ser confundido com uma mera ação - a marca distintiva de um ato face a uma ação consiste, por um lado, na sua conformidade (objetiva) às leis da obrigação e, por outro, na consciência, por parte do sujeito, de sua liberdade do arbítrio, ou seja, o sujeito ao praticar um ato se sabe submetido às relações morais implicadas no conceito de obrigação. $\mathrm{O}$ que aqui nos interessa, contudo, é que, ao contrário do que ocorre na ação, Kant sublinha que um ato não existe fora da relação com uma lei da obrigação $<$ Verbindlichkeit $>$.

Consideremos então o conceito de obrigação: “Obrigação é a necessidade de uma ação livre sob um imperativo categórico da razão" (DD Ak VI 222. p. 27).

Um ato, a realização de uma ação livre na medida em que o sujeito cobra consciência de sua liberdade aqui implicada, já pressupõe conformidade (objetiva) à lei moral, a um mandamento emanado da razão prática, visto que a seu conceito pertence o de obrigação, a qual não existe fora de uma relação moral, isto é, à parte de um imperativo categórico.

Como ocorre com outros conceitos centrais de sua filosofia moral, Kant altera o conceito de obrigação na "Metafísica dos Costumes" relativamente àquele exposto na "Fundamentação". Em decorrência dessa mudança, Kant afirma haver dois modos de obrigação, uma vez que esta agora não se refere exclusivamente à necessidade prática objetiva da ação "(como a que enuncia uma lei em geral), mas também [a uma] necessitação <Nöthigung>" (DD Ak VI 223. p. 28). Em um ato, ou seja, em uma ação "obrigatória", há tanto a conformidade objetiva a uma lei moral quanto uma necessitação sentida pelo agente para a realização dessa ação, necessitação essa que determina de que tipo de obrigação se trata. Vejamos com mais detalhes, a partir do conceito de dever, o que significa cada um desses elementos pertencentes ao conceito de "ato", sobretudo no que diz respeito aos dois modos de obrigação aqui envolvidos.

Analisemos, portanto, o conceito de dever. "Dever é a ação a que alguém está obrigado. É pois a matéria da obrigação, e pode ser o mesmo dever (segundo a ação), embora possamos a ele estar obrigados de diversos modos" (DD Ak VI 222. pp. 27-8, grifo meu).

Estar obrigado de um determinado modo significa estar sujeito a um tipo específico de obrigação - ao passo que o dever propriamente dito, isto é, a ação devida, objetivamente necessária, consiste na matéria da obrigação, o tipo de obrigação, a maneira pela qual se estabelece que determinada ação é devida, diz respeito, por assim dizer, à forma da mesma. 
De maneira a esclarecer essa clivagem entre forma e matéria, voltemonos à conhecida distinção kantiana entre legislação ética e legislação jurídica introduzida na "Metafísica dos Costumes":

Tem a ética, sem dúvida, os seus deveres peculiares (por exemplo, os deveres para consigo mesmo) mas tem também deveres comuns com o Direito, embora não o modo de obrigação. Realizar ações simplesmente porque são deveres e converter em móbil suficiente do arbítrio o princípio do próprio dever, venha este donde vier, é o peculiar da legislação ética (DD Ak VI 220. p. 25).

Realizar ações pois elas são deveres significa "não ter em conta nenhum outro móbil, [trata-se de um mandamento] que pertence apenas à legislação interior" (idem). Ou seja, na legislação ética ocorre um modo de obrigação distinto daquele presente na legislação jurídica; trata-se de uma necessitação ou coerção ${ }^{12}$ interna, muito embora a ação realizada, isto é, o dever, a matéria da obrigação, possa ser semelhante àquela requerida pela legislação jurídica. Esta, por seu turno, pelo fato de não exigir que a própria ideia de dever sirva de móbil para o arbítrio, envolve uma coerção externa, isto é, a ação requerida pode ser externamente imposta, o agente pode ser coagido por outrem a realizála. Bem entendido, é possível estar obrigados de duas formas distintas a realizar uma mesma ação - em outras palavras, relativamente à mesma matéria da obrigação (à ação praticamente necessária) posso estar sujeito a duas formas de obrigação (ao modo de obrigação ética ou ao modo de obrigação jurídica). A esse respeito, o conhecido exemplo de Kant é ilustrativo: um determinado sujeito pode cumprir um contrato (a ação praticamente necessária) seja por medo das sanções juridicamente estabelecidas ligadas à conduta contrária (modo de obrigação jurídica), seja porque ele acredita que fazê-lo é um dever ao qual assente (modo de obrigação ética).

Com a caracterização do dever como ação livre e objetivamente necessária e não, conforme ocorria na "Fundamentação", como "a necessitação de uma ação realizada por respeito à lei” (FMC Ak IV 400. p. 114. Grifo meu), chegamos ao ponto central desse momento da análise aqui proposta. Talvez com o objetivo de permitir algo como uma legislação jurídica no interior de uma "Metafísica dos Costumes", Kant opera uma modificação conceitual em

12 Kant utiliza frequentemente o termo Zwang (coerção) como sinônimo de Nötigung (necessitação) (p.ex: DV Ak VI: 279) e mesmo fala de uma Selbstzwang para designar a "coerção" interna sentida pelo agente ao agir em conformidade (subjetiva) a seus deveres de virtude (px: DV Ak VI: 394). Para evitar, porém, a conotação de um constrangimento externo que o termo carrega, adequado ao contexto do Direito, mas não ao da ética, preferimos utilizar o termo "necessitação" para designar a "(auto)coerção" da virtude, mantendo o termo "coerção" para o constrangimento externo presente no Direito. Agradecemos aqui à crítica e sugestão feita pelo parecerista anônimo. 
seu pensamento moral que pode ser tida por crucial quando confrontamos a "Metafísica dos Costumes" com suas obras morais anteriores: no interior mesmo do registro metafísico, o ato conforme ao dever, em oposição ao ato por dever, parece assumir a primazia na avaliação do estatuto moral de uma determinada conduta. Enquanto que na "Fundamentação" e na "Crítica da Razão Prática" a ênfase parecia recair unicamente na moralidade da ação, e não em sua legalidade, isto é, na ação por dever e não conforme ao dever, Kant agora parece realizar na sua "Metafísica dos Costumes" um deslocamento conceitual que enseja a possibilidade de pensarmos tanto o Direito quanto a legalidade ética no interior da parte metafísica de sua filosofia prática.

Vejamos, com ajuda de uma evidência textual, a forma pela qual essa possibilidade já está sistematicamente inscrita no próprio conceito supremo de divisão da "Metafísica dos Costumes":

Correto ou incorreto <recht oder unrecht $>$ (rectum aut minus rectum) em geral é um ato, na medida em que é conforme ao dever $<$ pflichtmäßig $>$ ou a ele contrário (factum licitum aut illicitum); seja de que tipo for o próprio dever quanto ao seu conteúdo ou quanto à sua origem (DD Ak VI 223. p. 29, grifo meu).

Trazendo novamente à mente a passagem em que Kant introduz o ato do livre arbítrio como conceito supremo do sistema, percebe-se que os mesmos termos em alemão (recht e unrecht) são empregados para designar tanto aquilo que é "partilhado" na divisão do conceito de ato do livre arbítrio, quanto o ato que é conforme ou não ao dever, ou seja, correto ou incorreto. Visto que dizemos ser correto ou incorreto apenas um ato, de acordo com o que até aqui foi exposto deve-se interpretar "conteúdo" e "origem" do dever como respectivamente matéria e forma da obrigação - ora, o conteúdo de um dever nada mais é do que aquilo que é prescrito na ação devida e sua origem consiste na legislação que obriga essa ação, a fonte donde provém a necessitação ou coerção para o cumprimento da ação exigida.

Dessa forma, o cenário que surge da interpretação realizada é o seguinte: caso seja levada ao limite a figura do ato do livre arbítrio como conceito supremo do sistema metafísico prático e seja assumido que aquilo por ele partilhado deve ser refletido no sistema dos costumes como o elemento mais primordial presente nos seus membros, é forçoso então admitir que de uma conduta qualquer inicialmente julgamos, de um ponto de vista moral e não estritamente ético, não se ela se dá por dever, isto é, se o agente pratica o seu dever tendo por móbil o pensamento de que se trata de um dever, mas antes se ela se dá conforme ao dever, isto é, se o agente ao realizar uma ação conforma-se de forma objetiva ao dever, sem que seus motivos para a ação 
sejam levados em conta - sem que, pois, a "origem" do dever, a forma da obrigação, entre nessa equação.

Em suma, de um ato se pergunta em primeiro lugar se ele é correto $<$ recht $>$, se ele se conforma objetivamente ao dever, e não se esse ato possui valor moral, se ele se conforma objetiva e subjetivamente ao dever. Adotando o ato do livre arbítrio como conceito supremo de uma "Metafísica dos Costumes", além da evidência de que a forma da divisão do sistema em legislação jurídica e legislação ética já está contida nele, somos levados a admitir - conforme uma terminologia introduzida por Kant na "Crítica da Razão Prática"13 e retomada por ele, com algumas modificações, na "Metafísica dos Costumes"14 - que a legalidade <Legalität $>$ assume prevalência em face da moralidade $<$ Moralität $>$ da ação; em outras palavras, numa Metafísica dos Costumes o moralmente correto tem primazia em relação ao moralmente bom. Essa tese não só tem influência direta na questão do pertencimento do Direito numa "Metafísica dos Costumes", como também permite que se conceba algo como uma legalidade ética, ou seja, uma conformidade apenas objetiva ao dever nos deveres de virtude. Refinemos na sequência esse juízo e vejamos em qual tradição interpretativa é possível inseri-lo.

\section{O Direito e a legalidade ética}

Com o argumento até aqui desenvolvido, é fornecido um apoio textual e sistemático a uma antiga tese na literatura sobre a filosofia moral kantiana. Essa tese, cujos maiores proponentes são talvez H. J. Paton e W. D. Ross, é aquela que sustenta o imperativo categórico como critério não apenas para o moralmente bom, mas também - e sobretudo - para o moralmente correto. ${ }^{15}$ Uma das inúmeras discussões mais recentes na Kant-Forschung diz respeito justamente à pertinência dessa análise quando confrontada com a "Doutrina da Virtude" e seus fins que são ao mesmo tempo deveres. Comentadoras como Barbara Herman (1993) e Márcia Baron (1995; 2002) excluem a

13 CRpra Ak V 71-2. p. 114.

14 Ver nota 4.

15 David Ross: "Eu creio que ele [Kant] descreve, de forma consistente, a ação por dever não como a única ação que é correta, mas como a única ação que tem valor moral, fazendo, dessa forma, do motivo (ou, como ele prefere chamá-lo, o princípio ou máxima da ação) o fundamento do ser-bom <goodness $>$ moral, mas [fazendo] da natureza da ação, à parte de seu motivo, o fundamento de seu ser-correto <rightness>" (Ross, 1939, p. 139). H. J. Paton: "É claro [...] que Kant entende o imperativo categórico como fornecendo-nos não apenas o critério para a ação moralmente boa, mas também o critério para ações corretas; e, de fato, ele nos comanda a realização de ações corretas como especificadas por esse critério" (Paton, 1958, p. 124). 
possibilidade de que o imperativo categórico se apresente como critério do moralmente correto no âmbito estritamente ético, recorrendo sobretudo aos deveres de virtude para justificar sua posição; já comentadores como Mark Timmons (2002) e Otfried Höffe (2001, pp. 105-106; 108-111) seguem Mary J. Gregor (1963, pp. 21-22) ao subscrever, com ressalvas, a interpretação de Paton e Ross, afirmando a plausibilidade de uma legalidade ética nos deveres de virtude. ${ }^{16}$ Antes de voltar-nos a esse tópico em específico, discutamos a questão do Direito como um exemplo paradigmático do tipo de interpretação equivocada que decorre da recusa da postura argumentativa até aqui defendida e que desemboca na negação de uma legalidade ética.

Allen Wood, um dos atuais expoentes da posição que defende a independência do Direito em face da metafísica prática kantiana, sustenta sua tese argumentando que o princípio universal do Direito e os deveres dele derivados não podem ser deduzidos diretamente do imperativo categórico entendido como princípio supremo da moralidade e fundamento de uma "Metafísica dos Costumes" (Wood, 2002, p. 9). Segundo ele, o fato de os deveres jurídicos e seu princípio supremo não exigirem um motivo moral ou seja, o pensamento mesmo de dever - para seu cumprimento, faz deles elementos autossubsistentes e independentes do sistema. ${ }^{17}$ A essa posição argumentativa subjaz uma pressuposição que foi posta em questão até aqui, a saber, a compreensão do imperativo categórico como um mandamento ético que estipula um critério unicamente para o moralmente bom, e não para o moralmente correto, exigindo o pensamento do dever, ou da racionalidade da ação, como parte do conteúdo mesmo dos deveres dele derivados. A recusa do pertencimento do Direito a uma metafísica prática decorre forçosamente dessa postura argumentativa combatida, já que os deveres jurídicos, como já dito, exigem unicamente uma conformação objetiva ao dever, e não uma motivação moral subjetiva - segundo uma concepção estrita do Direito, à qual Kant subscreve, eles devem ser avaliados segundo o critério do moralmente correto, e não do moralmente bom.

Contudo, assumindo o ato do livre arbítrio como conceito supremo de uma "Metafísica dos Costumes" e as consequências disso já mencionadas, a tese defendida por Wood e por demais autores cai por terra: entendido como base de um sistema metafísico prático que partilha inicialmente o correto e o

16 Cabe aqui ressaltar que o termo "legalidade ética" é cunhado pelo próprio Kant na reflexão 6764: "A legalidade é ou jurídica ou ética” (Ak XIX 154).

17 Uma recente obra retoma e expõe todo o debate entre os intérpretes que defendem a dependência da "Doutrina do Direito" em relação à filosofia moral de Kant e aqueles que a negam (Cf. Horn, 2014). Não entraremos em detalhes sobre esse ponto, limitando nossa análise à tese de Wood. 
incorreto, o imperativo categórico deve ser inicialmente capaz de estipular as condições para que um determinado ato seja considerado em conformidade ao dever, isto é, para que ele seja legal, conforme à lei, deixando as considerações acerca do motivo para um momento posterior da avaliação - a saber, se esse ato correto é igualmente moralmente bom, se ele possui valor moral. ${ }^{18} \mathrm{O}$ ato do livre arbítrio como conceito supremo de uma "Metafísica dos Costumes" deixa entrever que o critério inicial de julgamento de uma ação deve ser o de sua correção moral, unicamente o que permite aos deveres jurídicos figurar no sistema metafísico prático.

Assim, a exigência de um motivo moral fica restrita exclusivamente à Ética entendida no interior da moralidade, pertencendo, pois, a apenas um momento da "Metafísica dos Costumes", e não caracterizada como uma condição sine qua non de todos os deveres presentes no âmbito moral. Contudo, para que a tese aqui defendida seja plenamente consistente, é necessário que a legalidade se estenda a todo o edifício metafísico prático, aplicando-se inclusive aos deveres exclusivamente éticos, ou seja, aos deveres de virtude. Em uma palavra, é necessário que haja algo como uma "legalidade ética", entendida como a conformação objetiva ao dever nos deveres de virtude, independente dos motivos que levam o agente a cumpri-los. Dessa forma, seria possível, por exemplo, realizar um dever de beneficência mesmo a partir de motivos não morais - um agente estaria cumprindo objetiva ou materialmente seu dever de promover a felicidade alheia mesmo se com isso ele deseje, por exemplo, ser bem-visto pelos outros ou se para cumpri-lo ele seja movido por um prazer pela sua boa ação. Em tal caso, não seria o pensamento de dever que motiva o agente a cumprir o seu dever, mas sim um motivo egoísta, de autointeresse ou mesmo de indiferença à felicidade alheia. $\mathrm{O}$ mesmo valeria para os demais deveres de virtude, como por exemplo o de cultivo das disposições físicas unicamente por considerações de prudência.

Contudo - como objetam os defensores da tese forte do valor moral da ação -, ao operar esse nivelamento legalista nos deveres de virtude, o intérprete não estaria equivocadamente equiparando Ética com Direito, obscurecendo a

18 Em termos mais familiares ao leitor da "Fundamentação", um ato correto ser também um ato moralmente bom implica que o desejo do agente de que a máxima sob a qual aquele ato é subsumido torne-se uma lei universal seja motivo suficiente da ação, como exige a primeira formulação do imperativo categórico (FMC Ak 421. p. 129). Num processo de abstração, ou de recorte analítico, é possível remover essa exigência de adequação ou conformidade subjetiva da máxima a uma lei universal e ater-se apenas à adequação ou conformidade objetiva da ação ao processo de universalização no qual consiste a fórmula canônica do imperativo categórico. Reivindicar que o imperativo categórico não permite esse recorte analítico significa sobrecarregá-lo com um peso ético desnecessário, do qual, de resto, o sistema deve abrir mão de modo a manter-se em pé, e sem o qual este se enriquece ao abrir as portas para o Direito e para a legalidade ética. 
diferença específica dos deveres de virtude que consiste nestes exigirem a adoção de fins que são ao mesmo tempo deveres? E a adoção de um fim não é algo intimamente entrelaçado com o cultivo de uma disposição moral do agente e, assim, indissociável da presença de um motivo moral no momento de sua realização? Essas são fortes objeções à interpretação proposta e outras mais poderiam ser acrescidas à lista. Contudo, sem que o argumento se aferre em demasiado ao aspecto sistemático que abre a possibilidade de uma legalidade ética - o qual, contudo, constitui-se a nosso ver como um forte argumento -, há uma série de evidências textuais e mesmo doutrinais que autorizam a concepção de uma legalidade ética. Em virtude de falta de espaço, apenas sugeriremos algumas respostas a elas. ${ }^{19}$

Em primeiro lugar, caso de fato Kant entendesse que os deveres de virtude exigem não apenas uma conformidade objetiva, mas também uma conformidade subjetiva ao dever, então não haveria a necessidade de algo como o mandamento ético universal: "age em conformidade com o dever por dever" (DV Ak 391. p. 26) em acréscimo ao princípio supremo da doutrina da virtude - de resto, esse é também um forte argumento contra a tese que defende o imperativo categórico como um mandamento estritamente ético. Ora, é de esperar-se que Kant conhecesse muito bem o princípio de economia sistemática que afirma que duas normas que exigem a mesma coisa num ordenamento normativo servem apenas para torná-lo mais confuso. ${ }^{20}$

19 Uma resposta completa e convincente é fornecida por Mark Timmons (2002). O autor, contudo, afirma que o motivo moral influi, sim, no estatuto deontológico de alguns deveres de virtude, o que não significa que esse motivo faça parte do conteúdo desses deveres. O que ocorre é que alguns deveres de virtude têm o seu estatuto deontológico modificado em razão do motivo que leva o agente a cumpri-los, fazendo com que ações permitidas tornem-se proibidas, ações obrigatórias permitidas e assim por diante. Por exemplo, uma ação permitida, um gracejo ou um chiste, pode tornar-se proibida se feita por motivos maliciosos. Sem a pretensão de rebater o argumento de Timmons, notemos aqui apenas que o comentador passa por cima das dificuldades em determinar o "permitido" para Kant - ora, Timmons assume aproblematicamente que na "Metafísica dos Costumes" propriamente dita haja ações meramente permitidas, e não também ao mesmo tempo obrigatórias, o que parece contradizer a passagem em que Kant exclui a possibilidade de uma lex permissiva no âmbito ético, e não jurídico (DD Ak VI 223. p. 28. Sobre esse tema, ver Brandt, 1982). Para Kant, a situação de permissão identifica-se com a ausência de norma, ao passo que na esfera de vigência de uma lei o permitido confunde-se com o obrigatório: o que é permitido por lei é na realidade obrigatório, exigido pela lei. Em suma, uma conduta somente é de fato permitida (no sentido deontológico próprio do termo) se nenhuma norma incide sobre ela, o que certamente não ocorre num sistema de deveres, ou seja, de leis morais. Ademais, Timmons emprega exemplos retirados da casuística kantiana, que notadamente apresenta problemas quando colocada no interior do sistema metafísico de deveres conforme Kant o entendia.

20 "Também segundo Kant, uma ação, para ter valor moral, isto é, para ser moralmente boa, deve não só ser realizada 'por dever' (aus Pflicht) mas ainda estar 'em conformidade com o dever' (pflichtmäßig), isto é, corresponder à lei moral. A norma moral: não atues por inclinação mas 'por dever', pressupõe, portanto, outras normas morais que obrigam a determinadas ações. Uma das posições mais fundamentais da sua Ética é a de que 'o conceito do bom e do mau não deve ser determinado antes da lei moral [...], mas somente [...] segundo a mesma e através da mesma' [(CRPra Ak V 62-3. pp. 100-1)]" (Kelsen, 2000, p. 405n). Kelsen nitidamente interpreta a filosofia moral kantiana como constituída por um conjunto 
Em segundo lugar, num ato beneficente, por exemplo, é possível distinguir dois elementos: por um lado, há um aspecto externo (ação de ajuda) e, por outro, um aspecto interno (um estado de mente que motiva a ação de ajuda). Esse aspecto interno, por sua vez, não pode ser imediatamente identificado com o próprio fim de beneficência: ora, é possível que este fim esteja subordinado a um outro fim egoísta, como no caso do agente que adota o fim de beneficência com base, por exemplo, no objetivo de fundo de ser bem visto na sua comunidade - para esse fim egoísta a ação beneficente serviria apenas como um meio. Nesse sentido, a distinção entre Wohlwollen (benevolência) e Wohltätigkeit (beneficência) discutida por Otfried Höffe (2001, p. 115) ilustra bem o argumento. Segundo ele, "Wohltaten podem ser cumpridos não unicamente por dever, mas também por outras razões. O Wohlwollen, pelo contrário, é uma característica da vontade, apresentando-se não lá onde basta o simples dever de fazer o bem aos outros homens, mas lá onde o Wohltat se cumpre de fato pela vontade de fazer o bem aos homens". ${ }^{21}$ Em suma, o "agir-beneficente" $<$ Wohltat $>$ ou beneficência ocorre independentemente dos motivos do agente, já o "desejar-ser-beneficente" <Wohlwollen $>$ ou benevolência deve ser a disposição da vontade em promover a felicidade alheia tendo por motivo suficiente o pensamento do dever e não algum outro fim ou disposição egoísta. A distinção reside na motivação do agente ao realizar a ação que é objetivamente a mesma em ambas as situações. Trata-se em um caso de uma ação meramente correta e noutro de uma ação moralmente boa; em ambos os casos, contudo, trata-se do cumprimento - objetivo e/ou subjetivo - de um dever de virtude.

hierárquico de normas, no interior do qual a norma que estipula o comportamento eminentemente ético (o "mandamento ético universal") ocupa um lugar intermediário, subordinada assim à norma que prescreve a ação em conformidade ao dever. Em suma, para Kelsen, somente é concebível uma norma que afirma a necessidade de uma ação por dever se houver outras normas que estipulem uma determinada ação como devida, isto é, "que obrigam a determinadas ações". Ainda segundo Kelsen, essa interpretação tem apoio na tese kantiana de que a lei moral (aqui, norma moral que estipula uma ação como devida) precede o bom (aqui, valor moral da ação, a ação por dever). Cf. ainda, p. 406, nota: após citar DD Ak VI p. 214 - sobre a legalidade e a moralidade -, Kelsen acrescenta: "Quer dizer: também as normas jurídicas são normas morais, e também as normas morais, portanto, se dirigem às ações externas; apenas uma norma moral prescreve que nós devemos agir, não por inclinação, mas por consideração à lei [por dever]. Quando Kant diz que só a ação que corresponde a esta norma tem valor moral, distingue, pois, um valor moral em sentido estrito ou específico: concordância em relação a esta norma moral especial; e um valor moral em sentido amplo: concordância relativamente às outras normas morais. Também a legalidade é um valor moral, pois ela é concordância com normas 'morais'".

21 O argumento é apoiado pela escolha dos termos Wohlwollen e Wohltätig sein pelo próprio Kant nos distintos momentos em que discute o dever de beneficência. Na "Fundamentação", numa passagem em que a ênfase era na conformidade objetiva ao dever, o termo usado é Wohltätig sein (FMC Ak IV 398. p. 113); já na "Crítica da Razão Prática", quando Kant queria ressaltar a conformidade subjetiva a tal dever, o termo usado é o Wohlwollen (CRPra Ak V 82. p. 133). 
A discussão poderia ser decerto prolongada, bem como mais bem esclarecida a questão dos fins e motivos da ação. Esperamos, contudo, que o núcleo do argumento tenha ficado claro: é possível - e desejável - operar um corte analítico nos deveres presentes na "Metafísica dos Costumes", distinguindo a conformidade objetiva ao dever de sua motivação subjetiva, a qual pode ou não ser "moral", ou seja, ser o pensamento mesmo do dever. Esse corte analítico, de resto, é evidenciado pelo ato do livre arbítrio como conceito supremo do sistema, que de início exige unicamente a "correção" $<$ Richtigkeit $>$ da ação, isto é, sua conformidade objetiva ao dever. Para aqueles que ainda suspeitam dessa tese quando aplicada aos deveres de virtude, sugerimos esta seguinte consideração final: na "Doutrina da Virtude" - e, de um modo geral, na parte de sua filosofia prática voltada ao valor moral da ação - Kant está comprometido com dois projetos distintos: por um lado, estabelecer um sistema de deveres que não podem ser externamente coercitíveis, e, por outro, analisar o que é o caráter moral e seu desenvolvimento - a questão do motivo moral entra decisivamente apenas no segundo projeto, o da educação moral, que deve inculcar no homem o dever ético universal de agir meramente através do motivo do dever, de agir em conformidade ao dever por dever. ${ }^{22}$ Ora, se se trata de uma ambição, de um projeto a ser gradualmente concretizado, não é possível que a ação por dever seja o fundamento de possibilidade dos deveres de virtude. E, de fato, esse aspecto do agir moral não entra como elemento decisivo nem no imperativo categórico entendido como critério do moralmente correto, nem no conceito supremo do sistema dos costumes quanto ao último ponto, pretender que a ação por dever seja a mais elementar corresponde, grosso modo, à exigência de que a matéria em geral, e não o objeto em geral, seja o conceito supremo da filosofia transcendental. Assim como há objetos dos sentidos que não são objetos do sentido externo, há ações

22 Ver DV, Ak VI 390, pp. 25-6 (grifo meu e tradução modificada): “Embora nada seja meritório ajustar as ações ao Direito (ser um homem correto < rechtlicher Mensch>), é meritória, sim, a adequação da máxima de tais ações como deveres, isto é, o respeito pelo Direito. Pois, deste modo, o homem propõe-se como fim seu o direito da humanidade ou também dos homens, e alarga assim o seu conceito do dever para lá do conceito do devido (officium debiti): porque outrem pode, em virtude do seu direito, exigir de mim ações adequadas à lei, mas não que esta constitua também, simultaneamente, o seu móbil. O mesmo acontece com o mandamento ético universal: 'age em conformidade com o dever por dever'. É meritório fundar e avivar em si mesmo esta intenção, tal como a anterior, porque ela vai além da lei do dever das ações e, ao mesmo tempo, converte em móbil a lei em si”. Como se percebe, realizar o dever por dever (mandamento ético universal) é algo meritório, e não algo estritamente exigido no interior de uma "Metafísica dos Costumes". Ademais, ver DD Ak VI 227. p. 33: "É meritório (meritum) o que alguém faz a mais de acordo com o dever, em comparação com aquilo a que a lei o pode obrigar; e o que ele faz só em conformidade com esta última é devido (debitum)". A “lei”, i.e, o imperativo categórico, somente pode exigir o "devido" e não o meritório, aquilo feito "a mais", o "super-rogatório"; ou seja, somente pode exigir a conformidade ao dever, não a ação por dever. 
conformes ao dever que não são feitas por dever - toda ação por dever é também conforme ao dever, mas nem toda ação conforme ao dever é também uma ação por dever. Assumir essa dupla tese, o ato do livre arbítrio como conceito supremo e a legalidade como sistematicamente anterior à moralidade, permite compreender melhor a consistência sistemática da "Metafísica dos Costumes" e dirimir grande parte das objeções suscitadas em relação a ela - mesmo que à custa de uma compreensão de certo modo modificada da filosofia moral de Kant.

\section{Referências}

\section{Obras de Kant}

KANT, I. "Gesammelte Schriften". Königlich Preussischen Akademie der Wissenschaft. Ed Berlin. Lepizig: De Gruyter, 1922.

. "Fundamentação da Metafísica dos Costumes" (FMC). Trad. Paulo Quintela.

In: Textos Selecionados. Volume II (Pensadores). São Paulo: Abril Cultural, 1984.

. "Princípios Metafísicos da Ciência da Natureza" (PMCN). Trad. Artur

Morão. Lisboa: Edições 70, 1990.

. "Crítica da Razão Pura" (CRP). Trad. Valério Rohden e Udo Moosburger.

São Paulo: Nova Cultural, 1999.

" "Crítica da Razão Prática" (CRPra). Trad. Valério Rohden. São Paulo:

Martins Fontes, 2002.

. "Metafísica dos Costumes. Parte I - Princípios Metafísicos da Doutrina do

Direito" (DD). Trad. Artur Morão. Lisboa: Edições 70, 2004a.

. "Metafísica dos Costumes. Parte II - Princípios Metafísicos da Doutrina da

Virtude" (DV). Trad. Artur Morão. Lisboa: Edições 70, 2004b.

\section{Obras de comentadores}

ARENDT, H. "Lectures on Kant's Political Philosophy". Chicago: The University of Chicago Press, 1992.

BARON, M. "Kantian Ethics Almost Without Apology". Ithaca: Cornell University Press, 1995.

. "Love and Respect in the Doctrine of Virtue" In: TIMMONS, M (org.).

Kant's Metaphysics of Morals. Oxford: Oxford University Press, 2002.

BECK, L. W. "A Commentary on Kant's Critique of Practical Reason”. Chicago: Chicago University Press, 1960.

BRANDT, R. "Das Erlaubnisgesetz, oder: Vernunft und Geschichte in Kants Rechtslehre". In: BRANDT, R (Org). Rechtsphilosophie der Aufklärung. Berlin: De Gruyter, 1982.

DELBOS, V. "La Philosophie Pratique de Kant". Paris: PUF, 1969. 
FLIKSCHUH, K. "Freedom and Constraint in Kant's Metaphysical Elements of Justice". History of Political Thought, Vol. XX. Nr 2, 1999.

. "Kant and Modern Political Philosophy". Cambridge: Cambridge University Press, 2000.

FRIEDMAN, M. "Kant's construction of nature: a reading of the Metaphysical fundations of natural science". Cambridge: Cambridge University Press, 2013.

FULDA, H. F. "Deduktion der Einteilung eines Systems - erörtert am Beispiel "Metaphysische Anfangsgründe der Rechtslehre'". In: FULDA, H. F., STOLZENBERG, J. (orgs.). Architektonik und System in der Philosophie Kants. Hamburg: Meiner, 2001.

GOYARD-FABRE, S., FERRARI, J. (orgs.). "L'Année 1797. Kant. La Métaphysique des Moeurs". Paris: Vrin, 2000.

GREGOR, M. J. "Laws of Freedom. A Study of Kant's Method of Applying the Categorical Imperative in the Metaphysik der Sitten". Oxford: Basil Blackwell, 1963. GUYER, P. “Kant's System of Duties". In: . Kant's System of Nature and Freedom. Oxford: Oxford University Press, 2005a.

2005b.

. "Kant's System of Nature and Freedom". Oxford: Oxford University Press,

KELSEN, H. "Teoria Pura do Direito". Trad. João Baptista Machado. São Paulo: Martins Fontes, 2000.

HERMAN, B. "The Practice of Moral Judgement". Cambridge: Oxford University Press, 1993.

HORN, C. "Nichtideale Normativität: Ein neuer Blick auf Kants politische Philosophie". Frankfurt a/M: Suhrkamp, 2014.

HÖFFE, O. "Königliche Völker. Zu Kants Kosmopolitischer Rechts- und Frieden Theorie". Frankfurt: Suhrkamp, 2001.

HÖFFE, O. (org.). "Metaphysische Anfangsgründe der Rechtslehre". Berlin: Akademie Verlag, 1999.

PATON, H. J. "The Aim and Structure of Kant's Grundlegung". The Philosophical Quaterly, Vol 8, Nr. 31, 1958.

Press, 1971.

"The Categorical Imperative". Philadelphia: University of Pennsylvania

PLAASS, P. "Kants Theorie der Naturwissenschaft: eine Untersuchung zur Vorrede von Kants 'Metaphysischen Anfangsgründen der Naturwissenschaft"'. Göttingen: Vandenhoeck \& Ruprecht, 1965.

RENAUT, A. "L'Énracinement Critique de La Métaphysique des Moeurs". In: GOYARD-FABRE, S., FERRARI, J. (orgs.). L'Année 1797. Kant. La Métaphysique des Moeurs. Paris: Vrin, 2000.

1994.

. "Presentation". In: KANT, I. Metaphysique des Mouers I. Paris: Flammarion,

ROSS, D. "The Foundations of Ethics". Oxford: Oxford University Press, 1939. 
SÄNGER, M. "Die Kategoriale Systematik in den 'Metaphysischen Anfangsgründe der Rechtslehre"”. Berlin: De Gruyter, 1982.

SCHOPENHAUER, A. "Die Welt als Wille und Vorstellung. Bd I. Werke in Fünf Bänden”. Zürich: Haffmans Verlag, 1988.

TIMMONS, M. "Motive and Rightness in Kant's Ethical System". In: TIMMONS, M. (org.). Kant's Metaphysics of Morals. Oxford: Oxford University Press, 2002.

TIMMONS, M. (org.). "Kant's Metaphysics of Morals". Oxford: Oxford University Press, 2002.

VUILLEMIN, J. "Physique et métaphysique kantiennes". Paris: PUF, 1987.

WILLASCHEK, M. "Which Imperatives for Right? On the Non-Prescritive Character of Juridical Laws in Kant's Metaphysics of Morals". In: TIMMONS, M. (org). Kant's Metaphysics of Morals. Oxford: Oxford University Press, 2002.

WOOD, A. "Kant's Doctrine of Right: Introduction". In: HÖFFE, O. (org.). Metaphysische Anfangsgründe der Rechtslehre. Berlin: Akademie Verlag, 1999. . "The Final Form of Kant's Practical Philosophy". In: TIMMONS, M. (org.).

Kant's Metaphysics of Morals. Oxford: Oxford University Press, 2002. 